\title{
Diet and faecal flora in the newborn: lactoferrin
}

\author{
S E BALMER, P H SCOTT,* AND B A WHARTON \\ Sorrento Maternity Hospital and *Selly Oak Hospital, Birmingham
}

\begin{abstract}
SUMmARY The faecal flora of breast fed babies differs from that of bottle fed babies. We have shown that the use of a whey predominant formula rather than a casein predominant one induced a faecal flora generally closer to that of breast fed babies but substantial differences remained. The whey proteins of breast milk include much more lactoferrin than is found in cows' milk. Observations both in animals and in vitro suggest that lactoferrin could be responsible for some of these differences between bottle and breast fed babies. This study was designed to determine the effects on faecal flora of the addition of bovine lactoferrin to the diet of bottle fed babies while holding other qualities of their diet constant. As lactoferrin is an iron binding protein three test formulas were used: (a) no added iron and no added lactoferrin (basic), (b) no iron but added lactoferrin (L), and (c) added iron and lactoferrin (LF). The addition of lactoferrin had little effect upon the faecal microflora and did not move the pattern of the faecal flora in the direction of the breast fed baby. The addition of iron to the formula had more effect on the faecal flora than did lactoferrin. At day 4 it encouraged Escherichia coli and discouraged staphylococcal faecal colonisation. At day 14 the addition of iron to the formula discouraged bifidobacteria. The reasons why bovine lactoferrin was ineffective in vivo in this study are discussed.
\end{abstract}

We have shown previously that the faecal microflora of breast fed babies differs from that of formula fed babies and contains, in particular, more bifidobacteria and fewer Escherichia coli. ${ }^{12}$ One dietary factor responsible for this microbiological difference is the distribution of whey proteins and casein. Breast milk contains more whey proteins than casein. We have shown in the very young infant that compared with a casein predominant formula, a whey predominant infant formula results in a faecal flora closer to that of the breast fed baby. Nevertheless the faecal flora of the baby receiving a whey predominant formula is still substantially different from that of a breast fed baby. The whey proteins of cows' milk differ considerably from those of human milk. One difference is the presence in human milk of lactoferrin in relatively high concentrations $(100-$ $600 \mathrm{mg} / 100 \mathrm{ml}$ ). Lactoferrin has a high affinity for the small amounts of iron in breast milk so that the iron is unavailable for the multiplication of organisms. Lactobacilli are not affected by this mechanism, however, as they are one of the few organisms that thrive without iron. ${ }^{3}$ The bacteriostatic effect of lactoferrin is negated if extra iron is added to the system as this saturates the lactoferrin and leaves free iron available for the growth of other organisms. ${ }^{4}$
This explanation is, however, based mostly on in vitro observations, although a few have been made in animals. ${ }^{56}$ Bovine lactoferrin is now available in amounts sufficient for use in experimental situations. This has given us the opportunity to study in human babies the effects on faecal flora of the addition of lactoferrin.

\section{Subjects and methods}

DIET AND BABIES (TABLES 1 AND 2)

Table 1 gives details of the three formulas that were manufactured in special batches for the study by Nestlé. All formulas were based on demineralised whey, skimmed milk, and an identical fat blend. The 'basic' formula contained neither added lactoferrin nor added iron. The $\mathrm{L}$ formula consisted of basic plus lactoferrin and the LF formula consisted of basic plus lactoferrin plus iron.

Mothers on the postnatal wards of Sorrento Maternity Hospital, Birmingham, between January 1985 and March 1986, who had decided not to breast feed their babies, were approached by the project nurses. If they gave informed written consent their babies were allocated on a rotational basis to one of the three test formulas and remained on that 
Table 1 Composition of three test formulas and breast milk (per l)

\begin{tabular}{|c|c|c|c|c|}
\hline & \multirow{2}{*}{$\begin{array}{l}\text { Breast } \\
\text { milk }\end{array}$} & \multicolumn{3}{|l|}{ Formula } \\
\hline & & Basic & $L$ & $L F$ \\
\hline Protein g (nitrogen $\times 6 \cdot 38)$ & 11 & 17 & $19 \cdot 8$ & $19 \cdot 8$ \\
\hline Total 'true' protein $(\%)$ & $9(100)$ & $16(100)$ & $19(100)$ & $19(100)$ \\
\hline Caseins & $2 \cdot 5(28)$ & $6.4(40)$ & $6.4(34)$ & $6.4(34)$ \\
\hline Whey proteins & $6 \cdot 5(72)$ & $9 \cdot 6(60)$ & $9 \cdot 6(66)$ & $9 \cdot 6(66)$ \\
\hline$\alpha$ Lactalbumin & $2 \cdot 6(29)$ & $1.6(9)$ & $1.6(8)$ & $1.6(8)$ \\
\hline$\beta$ Lactoglobulin & 0 & $4 \cdot 2(26)$ & $4 \cdot 2(22)$ & $4 \cdot 2(22)$ \\
\hline Serum albumin & $0.5(6)$ & $0.4(3)$ & $0.4(2)$ & $0.4(2)$ \\
\hline Immunoglobulins & $1 \cdot 0-\operatorname{IgA}(11)$ & $1.4(9)$ & $1.4(7)$ & $1.4(7)$ \\
\hline Lysozyme & $0.5(6)$ & 0 & 0 & 0 \\
\hline Human lactoferrin & $1.8(20)$ & 0 & 0 & 0 \\
\hline Added bovine lactoferrin (g) & 0 & 0 & $2 \cdot 8(15)$ & $2 \cdot 8(15)$ \\
\hline Iron $(\mathrm{mg})$ & 0.76 & 0.4 & $0 \cdot 8$ & $9 \cdot 16$ \\
\hline Phosphorus (mg) & 150 & 300 & 300 & 300 \\
\hline
\end{tabular}

Table 2 Data of babies taking part in the study

\begin{tabular}{|c|c|c|c|}
\hline & \multicolumn{3}{|c|}{ Formula } \\
\hline & $\begin{array}{l}\text { Basic } \\
(n=20)\end{array}$ & $\begin{array}{l}L \\
(n=18)\end{array}$ & $\begin{array}{l}L F \\
(n=20)\end{array}$ \\
\hline \multicolumn{4}{|l|}{ Sex: } \\
\hline Male & 11 & 6 & 12 \\
\hline Female & 9 & 12 & 8 \\
\hline \multicolumn{4}{|l|}{ Race: } \\
\hline White & 13 & 14 & 12 \\
\hline Asian & 4 & 4 & 8 \\
\hline Afro-Caribbean & 3 & 0 & 0 \\
\hline \multicolumn{4}{|l|}{ Mode of delivery: } \\
\hline Normal vaginal & 15 & 12 & 12 \\
\hline Caesarean section & 5 & 6 & 8 \\
\hline Mean (SD) birth weight (g) & $\begin{array}{l}3230 \\
(530)\end{array}$ & $\begin{array}{l}3050 \\
(480)\end{array}$ & $\begin{array}{l}3120 \\
(470)\end{array}$ \\
\hline \\
\hline $\begin{array}{l}\text { Mean (SD) haemoglobin } \\
(\mathrm{Hb})(\mathrm{g} / \mathrm{l})\end{array}$ & $\begin{array}{l}172 \cdot 1 \\
(25 \cdot 9)\end{array}$ & $\begin{array}{l}183 \cdot 7 \\
(24 \cdot 0)\end{array}$ & $\begin{array}{l}171 \cdot 9 \\
(18 \cdot 0)\end{array}$ \\
\hline $\begin{array}{l}\text { Mean (SD) erythrocyte } \\
\text { protoporphyrin } \\
(\mu \mathrm{g} / \mathrm{g} \mathrm{Hb})\end{array}$ & $\begin{array}{l}1.67 \\
(1.04)\end{array}$ & $\begin{array}{l}1.45 \\
(0 \cdot 67)\end{array}$ & $\begin{array}{l}1.42 \\
(0.57)\end{array}$ \\
\hline
\end{tabular}

formula for 14 days. The powdered formulas were reconstituted by one of two project nurses and delivered to the babies' mothers in hospital and at home. Feeds were given on demand. Babies were fed one of the special formulas for 14 days.

PROCEDURES

Anthropometric measurements were made on day 1 . Faeces were collected on days 4,11 , and 14 . The specimens collected on days 4 and 14 were used to measure the bacterial flora and the 24 hour specimen collected on day 11 was used to estimate the faecal lactoferrin concentration. A heelprick specimen of blood was taken on day 14 .

\section{MICROBIOLOGICAL METHODS}

The methods used were exactly as described previously. ${ }^{1}$

\section{FAECAL BOVINE LACTOFERRIN}

The faeces were homogenised in $100 \mathrm{ml}$ phosphate buffered saline, centrifuged and filtered through Whatman glass microfibre filters GF/D. The filtrate diluted 1 in 200 was used in a two site solid phase enzyme immunoassay using labelled polystyrene beads.

Beads, washed in absolute alcohol and rinsed three times in phosphate buffered saline, were labelled with antibovine lactoferrin antibody (raised in a rabbit by $\mathrm{Dr}$ SJ Fairweather-Tait, Food Research Institute, Norwich) by incubating at $5^{\circ} \mathrm{C}$ overnight, and $200 \mu \mathrm{l}$ myoglobin $(20 \mathrm{~g} / \mathrm{l})$ was added and incubated at $37^{\circ} \mathrm{C}$ for 1.5 hours. Beads were ready for use in the assay after three washes with phosphate buffered saline.

The assay was performed in glass test tubes with one glass bead to which $150 \mu \mathrm{l} 5 \%$ albumin and $20 \mu \mathrm{l}$ filtrate or standards were added. Bovine lactoferrin standards were supplied by Nestlé. Incubation was carried out overnight on an orbital shaker at room temperature. After washing, $300 \mu$ l lactoferrin conjugate (Serotec) was added and incubated at $37^{\circ} \mathrm{C}$ for 1.5 hours. After further washing the bead was transferred to a polystyrene test tube, $300 \mu \mathrm{l}$ o-phenylenediamine was added, and it was incubated in the dark for 30 minutes. The reaction was stopped 
with the addition of $1.5 \mathrm{ml} \mathrm{M}$ hydrochloric acid. Absorbance was measured at $410 \mathrm{~nm}$. The results are expressed as $\mathrm{mg}$ lactoferrin per day.

\section{STATISTICAL ANALYSIS}

The results were analysed statistically using Student's $t$, Mann-Whitney, $\chi^{2}$, and Fisher's exact test as appropriate.

ETHICAL APPROVAL

Approval for the study was obtained from the ethics committee of the South Birmingham Health Authority.

\section{Results}

\section{MICROBIOLOGY}

Results are presented in detail in the same way as in the two preceding papers: (1) the counts of individual organisms examined in each baby, analysed statistically using the Mann-Whitney test and the presence or absence of an organism analysed by the

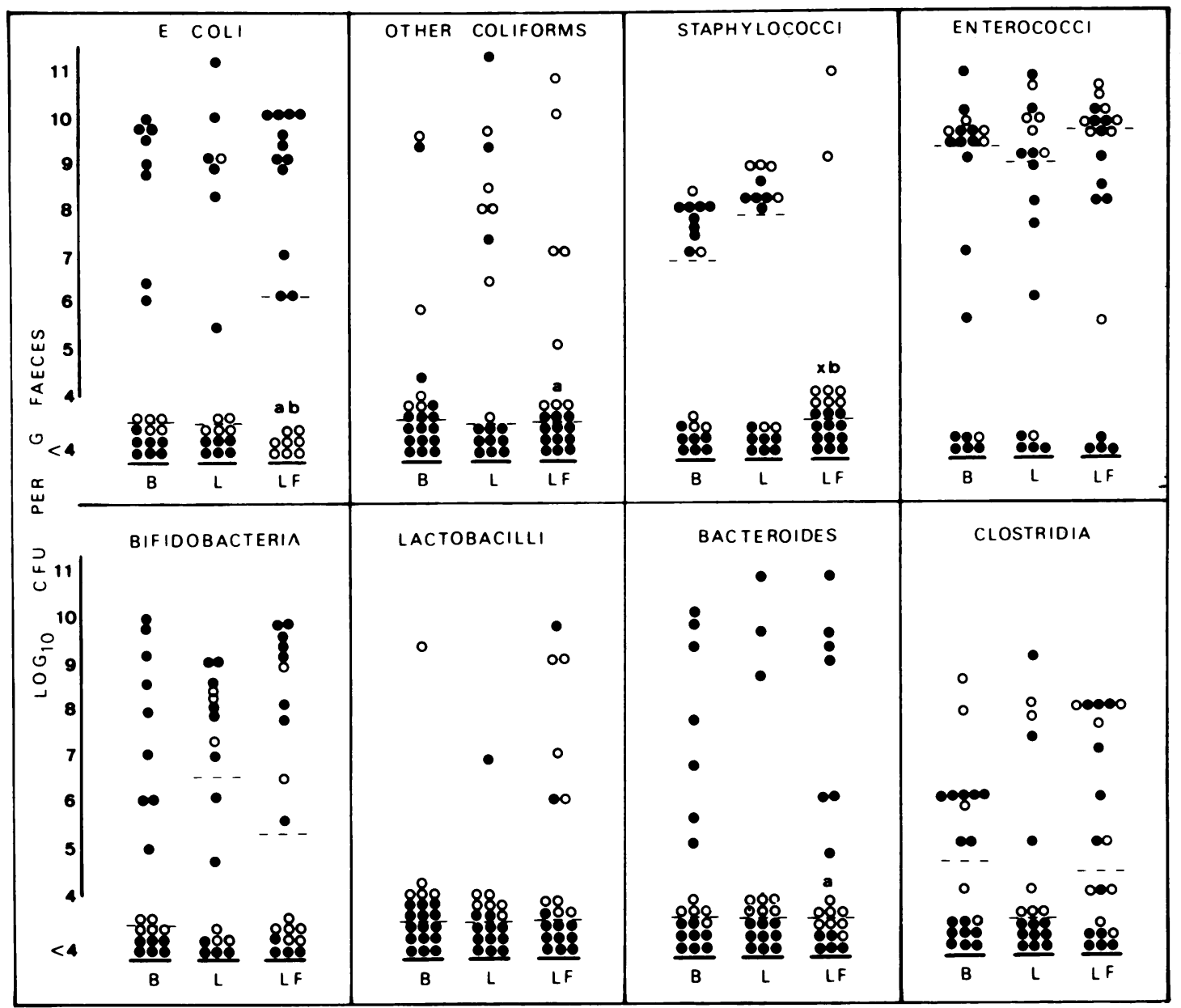

Fig 1 Counts of individual organisms ( $\log _{10}$ colony forming units (CFU) per $g$ of faeces) in the three dietary groups (basic (B), L, and LF formulas) on day 4. Median count shown by horizontal broken line. a, Proportion of section delivered babies in whom an organism was not detected is significantly different $(p<0.05)$ from vaginally delivered babies in the same dietary group ( $\chi^{2}$ with Yates's correction); $b$, proportion of vaginally delivered babies in whom an organism was not detected is significantly different $(p<0.01)$ for vaginally delivered babies fed either basic or L formula $\left(\chi^{2}\right.$ with Yates's correction); $x$, proportion of babies, regardless of delivery, in whom staphylococci were not detected is significantly greater $(p<0.05)$ than those fed either basic or $L$ formula ( $\chi^{2}$ with Yates's correction). $O=$ Babies delivered vaginally and $\mathrm{O}=$ babies delivered by caesarean section. 


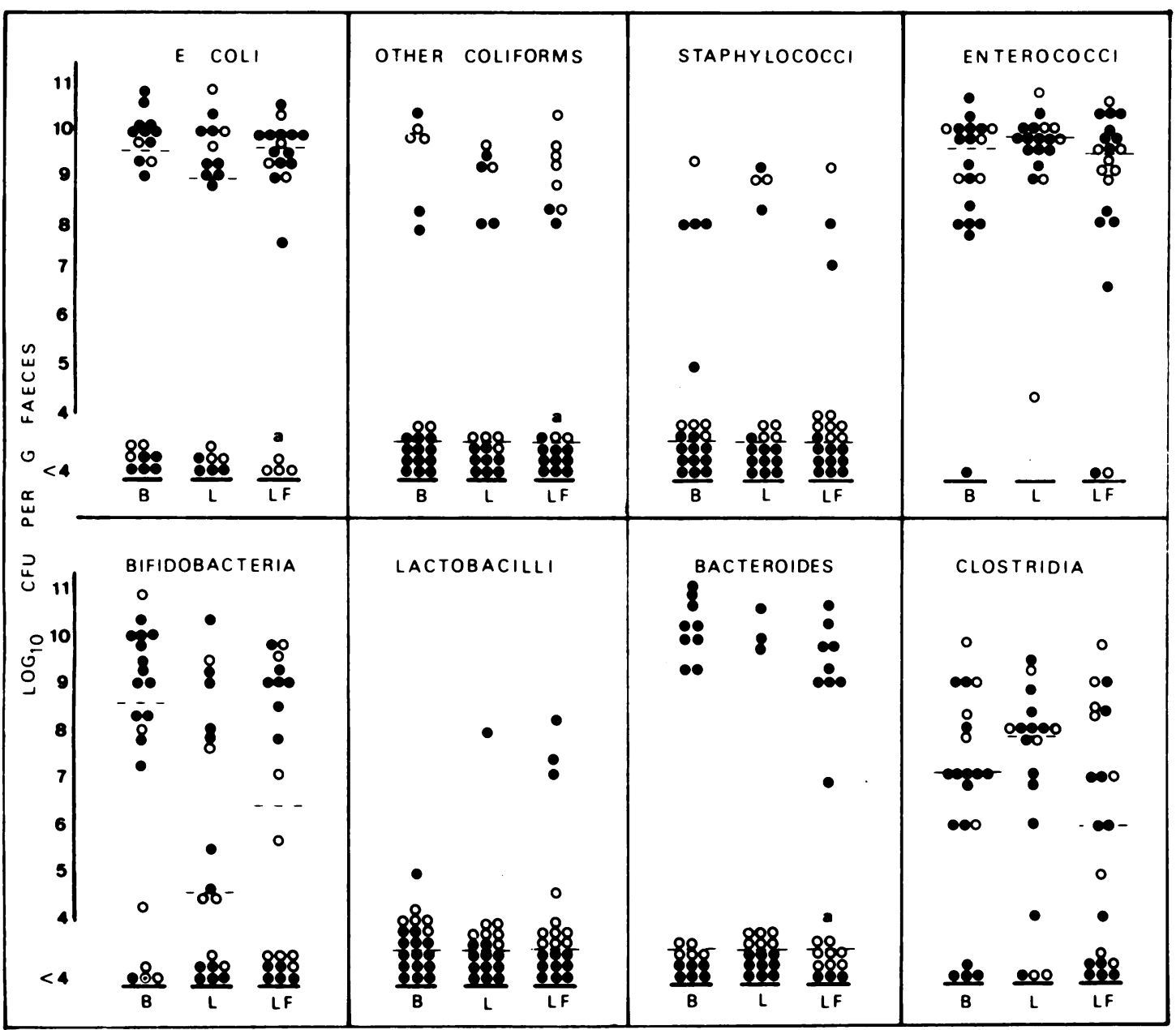

Fig 2 Counts of individual organisms (log ${ }_{10}$ colony forming units (CFU) per $g$ of faeces) in the three dietary groups (basic (B), L, and LF formulas) on day 14. Median count shown by horizontal broken line. a, Proportion of section delivered babies in whom an organism was not detected is significantly different $(p<0.001)$ from vaginally delivered babies in the same dietary group ( $\chi^{2}$ with Yates's correction). $\mathrm{O}=$ Babies delivered vaginally and $\mathrm{O}=$ babies delivered by caesarean section.

$\chi^{2}$ test (figs 1 and 2). (2) Patterns of dominance in individual babies (that is, a particular genus accounting for highest count in the bacterial population examined) analysed by the Fisher's exact test (fig 3).

\section{Day 4}

(1) Counts of individual organisms (fig 1)

(a) Mode of delivery-Differences were only apparent in the babies on formula LF. When comparing those babies born by caesarean section with those delivered vaginally (columns marked $a$ in the figure) there were: (i) fewer babies delivered by section who were colonised by $E$ coli (nil compared with $100 \%$, $\mathrm{p}<0.001$ ) and bacteroides (nil compared with $58 \%$, $\mathrm{p}<0.05)$.

(ii) more babies delivered by section who were colonised by other coliforms ( $62 \%$ compared with nil, $\mathrm{p}<0 \cdot 001$ ).

(b) Dietary differences-As the mode of delivery has caused differences, the effect of diet has been determined in the two groups separately. Results in the groups of babies on the basic and $L$ formula 
groups were not different. The babies on formula LF differed from babies on the other two formulas in that there were more of them colonised with $E$ coli and fewer with staphylococci (columns marked $\mathrm{b}$ and $\mathrm{x}$ in the figure).

\section{(2) Patterns of dominance (fig 3)}

No significant differences were detected.

Day 14

(1) Counts of individual organisms (fig 2)

(a) Mode of delivery-The differences in the babies on formula LF still persisted (columns marked a in the figure).

(b) Dietary differences-None were detected.

(2) Patterns of dominance (fig 3)

Bifidobacteria were the dominant organism in $25 \%$ of the groups on the basic formula compared with none of the group on formula LF (Fisher's exact test, $p=0.02$ ). The babies on formula $L$ did not differ from those on formula LF. When the group on formula $\mathrm{L}$ was combined with the group on basic formula there was still an increased dominance of
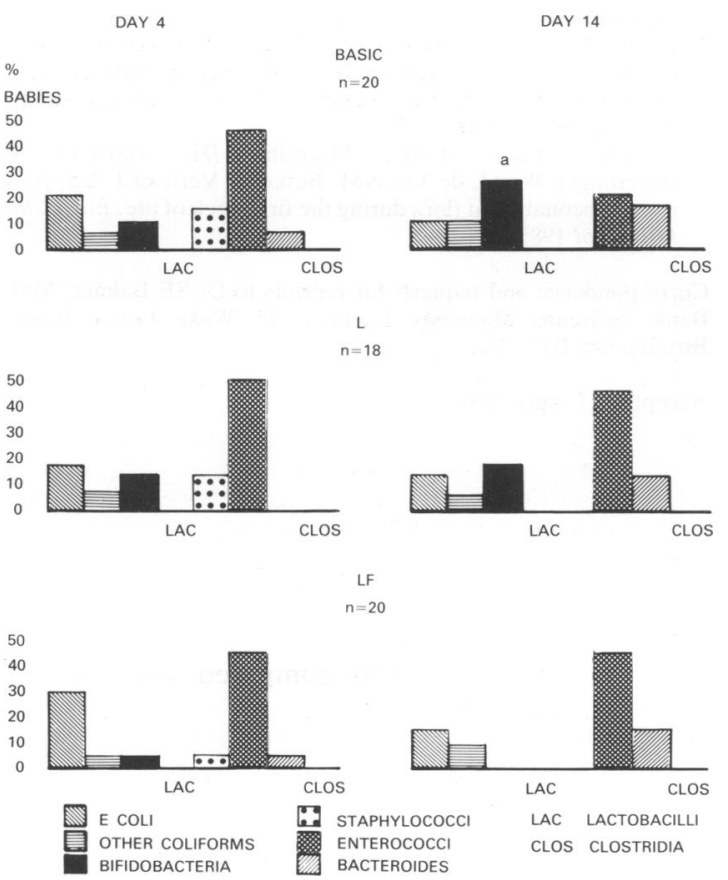

Fig 3 Percentage of babies in whose faeces organisms were dominant on days 4 and 14; $a=$ number of babies significantly different $(p=0.02)$ from babies fed on formula LF (Fisher's exact test).
Table 3 Lactoferrin excretion in the faeces on day 11. Results are $\mathrm{mg} /$ day bovine lactoferrin

\begin{tabular}{llll}
\hline & Formula & & \\
\cline { 2 - 4 } & $\begin{array}{l}\text { Basic } \\
(n=20)\end{array}$ & $\begin{array}{l}L \\
(n=18)\end{array}$ & $\begin{array}{l}L F \\
(n=20)\end{array}$ \\
\hline Range & $0-2 \cdot 2$ & $2 \cdot 4-7 \cdot 1$ & $1.9-6 \cdot 0$ \\
Mean (SD) & $0.55(0.65)$ & $4 \cdot 50(1.52)$ & $3.67(1.53)$ \\
\hline
\end{tabular}

bifidobacteria compared with the group on formula LF (22\% compared with nil, Fisher's exact test, $\mathrm{p}=0.03)$.

\section{FAECAL LACTOFERRIN CONCENTRATION}

Table 3 shows the range of concentrations of lactoferrin in the faeces of all the babies. As expected the babies fed formulas containing lactoferrin ( $L$ and $L F$ ) excreted significantly more lactoferrin in their faeces than babies who were fed the basic formula $(p<0 \cdot 001)$. However, the observed excretion was substantially below the estimated average intake of babies weighing $3100 \mathrm{~g}$ (approximately $1300 \mathrm{mg}$ daily). No correlation was found between the count of $E$ coli in the infants' faeces on day 14 and the concentration of lactoferrin at day 11 regardless of whether they were fed a formula containing lactorferrin.

\section{Discussion}

If the lactoferrin was biologically active then according to the hypothesis we would expect (i) the addition of bovine lactoferrin to the basic formula (making it $\mathrm{L}$ formula) would have resulted in a change in the pattern of faecal flora in the direction of breast milk, and (ii) the addition of both lactoferrin and iron to the basic formula (to make LF formula) would reverse this trend, thus the flora of babies fed the basic and LF formulas would have a similar pattern.

These predictions based on the hypothesis were clearly not seen. The addition of lactoferrin to the basic formula had little or no effect upon the faecal flora as babies fed both basic and $\mathrm{L}$ formulas were similar. As lactoferrin was not associated with a movement of the pattern from the non-fortified basic formula towards that of the breast fed baby the second test of the hypothesis (that is, a reversal of the trend) really becomes redundant. In fact the addition of lactoferrin and iron did have a significant effect but not in the direction of a breast fed flora. At day 4 more babies on formula LF were colonised by $E$ coli and fewer by staphylococci; at day 14 none of the babies on formula LF had dominant bifidobacteria. 
Moreover only a minute amount of the ingested lactoferrin appeared intact in the faeces of the babies in our study; this suggests it had been broken down or degraded higher in the gut. Certainly the excretion of human lactoferrin by breast fed babies is reported in the range $5.7-23.6 \mathrm{mg} / \mathrm{day}$, with the average faecal output amounting to only $1.1 \%$ of the lactoferrin ingested in the $\operatorname{diet}^{7}$ and our own observations (unpublished) are similar.

The ineffectiveness of the lactoferrin in vivo in this study could be due to one of three reasons: (a) the hypothesis based on the in vitro studies is not a reflection of what happens in babies, or (b) we used bovine lactoferrin and not human lactoferrin and this may have attracted foreign protein responses, or (c) other features of the system prevented the lactoferrin from being biologically active. In vitro studies have shown that bovine lactoferrin requires bovine antibodies (mainly IgG) and the complement cascade, lysozyme, and the presence of bicarbonate for it to be biologically active..$^{8-10}$ None of these factors were present in the formula. Generally therefore we favour explanations (b) and (c) for the lack of activity of the lactoferrin, but (a) cannot be excluded by the results of this study.

It is interesting that the addition of iron to the formula influenced the colonisation pattern, generally moving the faecal flora away from that seen in breast fed babies. Similar observations concerning iron fortification have been shown by MevissenVerhage et al. ${ }^{11}$ This is of considerable potential importance both in our scientific understanding of factors affecting the gut and in infant feeding practice. We are currently examining the phenomenon further.

This project was partially supported by Nestlé (Nestec Ltd, Research Centre), CH 1800 Vevey, Switzerland. We are grateful to
Mrs C Boyle and Mrs N Burton for the preparation of feeds and the collection of specimens.

\section{References}

1 Balmer SE, Wharton BA. Diet and faecal flora in the newborn: breast milk and infant formula. Arch Dis Child 1989;64:1672-7.

2 Balmer SE, Scott PH, Wharton BA. Diet and faecal flora in the newborn: casein and whey proteins. Arch Dis Child 1989;64: 1678-84.

3 Archibald FS. Lactobacillus plantorum an organism not requiring iron. Federation of European Microbiological Societies Letters 1983;19:29-32.

${ }^{4}$ Dolby JM, Stephens S, Honour P. Bacteriostasis of E coli by milk II. Effect of bicarbonate and transferrin on the activity of infant feeds. J Hyg (Camb) 1977;8:235-42.

5 Bullen JJ, Rogers HJ, Leigh L. Iron binding proteins in milk and resistance to Escherichia coli infection in infants. $\mathrm{Br} \mathrm{Med} \mathrm{J}$ 1972;i:69-75.

${ }^{6}$ Moreau MC, Thomasson M, Ducluzeau R, Raibaud P. Cinetique d'establissement de la microflora digestive chez le nouveau-ne humain en fonction de la nature du lait. Reprod Nutr Dev 1986;26(2B):745-53.

7 Prentice A, Ewing G, Roberts SB, et al. The nutritional role of breast milk IgA and lactoferrin. Acta Paediatr Scand 1987;76: 592-8.

8 Griffiths E, Humphreys J. Bacteriostatic effect of human milk and bovine colostrum on $\mathrm{E}$ coli: importance of bicarbonate. Infect Immun 1977;15:396-401.

9 Spik G, Jorieux S, Mazurier J, Navarro J, Romond C, Montreuil $\mathrm{J}$. Characterisation and biological role of human lactotransferrin complexes. In: Williams AF, Baum JD, eds. Human milk banking. Vevey: Nestlé Nutrition and New York: Raven Press, 1984:133-43.

10 Reiter B, Brock JH, Steel ED. Inhibition of E coli by bovine colostrum and post colostral milk. II. The bacteriostatic effect of lactoferrin on a serum susceptible and serum resistant strain. Immunology 1975;28:83-95.

$"$ Mevissen-Verhage EAE, Marcellis JH, Harmsen-van Amerongen WCM, de Vos NM, Berkel J, Verhoef J. Effect of iron on neonatal gut flora during the first week of life. Eur J Clin Microbiol 1985;4:14-8.

Correspondence and requests for reprints to Dr SE Balmer, Milk Bank, Sorrento Maternity Hospital, 15 Wake Green Road, Birmingham B13 9HE.

Accepted 17 April 1989 